\title{
Improvement of the compression ignition behaviour and combustion efficiency of the second generation biofuel BIOXDIESEL
}

Biodiesel fuel is covering more and more place in the market. The reason is a limited fossil fuels resources and the need to reduce emission of harmful substances by application of the fuel made of renewable resources. Currently in Poland and in Europe, the Fatty Acid Methyl Esters are used as biocomponent of the biodiesel fuel or it is used as pure biodiesel fuel. This paper presents the research on the biofuel, which contains mainly Fatty Acid Ethyl Esters, (the energetic value of FAEE is higher than FAME) and mineral Diesel fuel is a small addition. This paper presents research on the improvement of the compression ignition behaviour and combustion effectiveness of the second generation biofuel BIOXDIESEL, which contains up to 75\% of biocomponents (FAEE with bioethanol) with addition of mineral Diesel fuel. Improvement of the auto-ignition properties is achieved through the multi-component composition of Bioxdiesel fuel and dosing of enriching additives. The quality of the fuel has been evaluated during engine testing and during laboratory measurement of fuel parameters. Whereas satisfactory results show that it is appropriate to supplement the composition of biofuels produced from waste vegetable and animal fats and alcohol with the refining additive.

Key words: biodiesel, fatty acid ethyl esters, compression ignition engines

\section{Introduction}

Modern Diesel engines and increased environmental attention require constant improvement of the physical and chemical properties of the fuel obtained during crude oil processing. This improvement is achieved both on the way of refinery processing and by dosing of various types of additives.

One of the most popular enriching additives are those used in order to increase low temperature behaviour of the Diesel fuel used in cold climate conditions. Some other additives are used to increase storage ability of fuel by improving oxidation stability and the biocydes to eliminate microorganisms, which presence increase biodegradation of fuel are used to increase to lifetime of the fuel. One of the most important group of the additives are those, which are increasing cetane number of the fuel. The value of cetane number is responsible for compression ignition properties of the fuel, which are significantly important during variable load of the engine, ie in non-stationary conditions.

Properties of pure biodiesel fuels, consisting only Fatty Acid Methyl Esters FAME or Fatty Acid Ethyl Esters FAEE, are very similar to the properties of mineral Diesel fuel. Main differences between FAME or FAEE and the fuel standard are related to the flash point, cetane number, low temperature properties - cloud point $(\mathrm{CP})$ and cold filter plugging point (CFPP), kinematic viscocity and density. Comparison of the selected properties of FAEE, FAME and Diesel fuel are presented in Table 1.

Table 1. Selected properties of FAEE, FAME and Diesel fuel

\begin{tabular}{|l|c|c|c|}
\hline Properties & FAEE & FAME & Diesel Fuel \\
\hline Flash Point $\left[{ }^{\circ} \mathrm{C}\right]$ & 135 & 101 & 55 \\
\hline Cloud Point $\left[{ }^{\circ} \mathrm{C}\right]$ & -8 & -6 & -10 (grade F) \\
\hline $\begin{array}{l}\text { Cold Filter Plugging Point } \\
{\left[{ }^{\circ} \mathrm{C}\right]}\end{array}$ & -11 & -16 & -20 (grade F) \\
\hline Cetane Number $(\mathrm{CN})$ & 49 & 47 & 51 \\
\hline $\begin{array}{l}\text { Kinematic viscosity at } \\
40^{\circ} \mathrm{C}\left[\mathrm{mm}^{2} / \mathrm{s}\right]\end{array}$ & 4.5 & 3.5 & 2 \\
\hline Density at $15^{\circ} \mathrm{C}\left[\mathrm{kg} / \mathrm{m}^{3}\right]$ & 877 & 860 & $820-845$ \\
\hline Calorific value $[\mathrm{MJ} / \mathrm{kg}]$ & 39 & $36-38$ & 42.8 \\
\hline
\end{tabular}

Properties, presented in the table above can be adjusted by dosing the right additives. Low temperature properties of Diesel fuel are season depending. The PN-EN 590 standard divides fuel into 6 grades depending on season. For arctic or severe winter climate the CP and CFPP are set to $-34^{\circ} \mathrm{C}$ and $-44^{\circ} \mathrm{C}$ respectively.

The possibilities of cetane number $(\mathrm{CN})$ improvement of Diesel fuel and/or BIODIESEL by use of specially selected additives has been a subject of many research. In [1] authors test various types of $\mathrm{CN}$ improvers and test the presence of $\mathrm{CN}$ improvers in various fraction of distilled fuel.

In [2] author test the Diesel engine fed with different biodiesel fuel (containing methyl esters) with $\mathrm{CN}$ improvers and measure energetic and exergetic behaviour of the engine.

An influence of cetane number improvers on performance of biodiesel fuel containing FAME is also presented in [3], where authors also study influence of $\mathrm{CN}$ improvers on coking of the fuel injector nozzles.

\section{Preparation of the samples of the BIOXDIESEL \\ fuel}

Bioxdiesel fuel is a composition of bio-components containing Fatty Acid Ethyl Esters and/or Fatty Acid Methyl Esters with bioethanol and an addition of mineral Diesel fuel. The BIOXDIESEL fuel has been previously tested during the fleet vehicle testing over long distance $[4,5]$. Papers $[4,5]$ indicate good properties of the three component fuels in application for the Diesel engines. However, some of the properties still require improvement.

The samples of the FAEE used to prepare the BIOXDIESEL fuel were obtained on the way of the transesterification with bioethanol reaction of the waste animal (poultry and pork) fats and waste vegetable fats (frying oil), with small addition of rapeseed oil in the presence of alkali $(\mathrm{KOH})$ catalyst. The reaction has been performed with the use of laboratory scale set up, which contains vacuum evaporator to separate excess of bioethanol (see Fig. 1). 
Further, the glycerine is separated from FAME on the way of sedimentation. Fatty acid ethyl esters obtained in above described way are the base of the biofuel BIOXDIESEL (approximately 70\%). Further, the standard Diesel fuel, purchased in local fuel station has been added (approx. 25\%). The last ingredient was bioethanol (approx. 5\%).

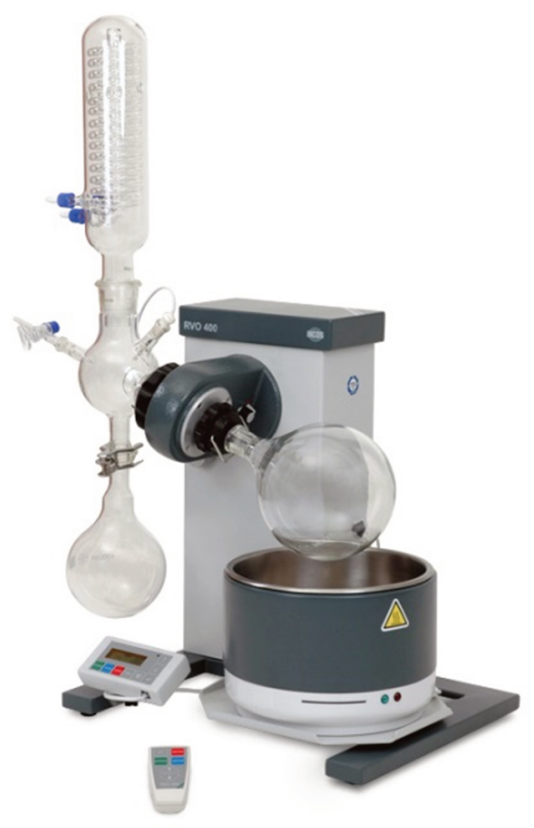

Fig. 1. The set up used to perform the transesterification reaction

\section{Improvement of the low temperature properties of the BIOXDIESEL fuel}

Pure biodiesel fuel, which contains only FAME or FAEE has similar properties as the mineral Diesel fuel. Main differences are related to low temperature behavior of the fuel. The standards (eg. PN-EN 590) are specifying the values of main parameters (CP and CFPP) as climate dependent requirements. So the fuel, which contains only esters can easily be used as a fuel in the regions with mild or warm climate conditions. To use the biodiesel fuel in colder weather condition, it would be necessary to improve the values of the CP and CFPP parameters.

There are various strategies to meet standardized requirements. One of the methods is to prepare the blended fuel, which contains both FAME and/or FAEE as well as mineral Diesel fuel. In such a case, mineral Diesel content would have to be increased. Table 2 presents the results of the low temperature testing of the fuel samples with various FAEE content. It is noticeable, that even for the samples, with maximum $80 \%$ of the mineral Diesel content, the lowest values of CP and CFPP does not meet the standard requirements for colder climate conditions.

Table 2. Low temperature properties of the fuel with various FAEE content

\begin{tabular}{|c|c|c|c|c|}
\hline Sample & $\begin{array}{c}\text { FAEE } \\
\text { content }[\%]\end{array}$ & $\begin{array}{c}\text { Diesel } \\
\text { content }[\%]\end{array}$ & $\mathrm{CP}\left[{ }^{\circ} \mathrm{C}\right]$ & $\mathrm{CFPP}\left[{ }^{\circ} \mathrm{C}\right]$ \\
\hline B20 & 20 & 80 & -10 & -12 \\
\hline B30 & 30 & 70 & -7 & -12 \\
\hline B40 & 40 & 60 & -5 & -9 \\
\hline B50 & 50 & 50 & -4 & -6 \\
\hline
\end{tabular}

The other method would be related with dosing cold flow additives to improve the cold flow properties of the fuel, which contains only FAEE (without addition of mineral fuel). The result of the improvement of the CFPP is shown in Table 3. The CFPP of pure FAEE has been improved significantly by $6^{\circ} \mathrm{C}$.

Table 3. Improvement of the FAEE cold flow properties by addition of cold flow improving additives

\begin{tabular}{|c|c|c|c|}
\hline Sample & $\begin{array}{c}\text { Cold flow } \\
\text { improver con- } \\
\text { tent }\end{array}$ & $\begin{array}{c}\text { Biocyde and } \\
\text { oxidation stability } \\
\text { additive content }\end{array}$ & $\begin{array}{c}\text { CFPP } \\
{\left[{ }^{\circ} \mathrm{C}\right]}\end{array}$ \\
\hline B100-1 & 0 & 0 & -12 \\
\hline B100-2 & $4000 \mathrm{ppm}$ & $250 \mathrm{ppm}$ & -18 \\
\hline
\end{tabular}

The other strategy of improvement of cold flow properties of the FAEE fuel would be a combination of addition of mineral Diesel fuel and cold flow improving additives.

Table 4. Cold flow properties of the fuel containing FAEE and mineral Diesel fuel with cold flow improving additives

\begin{tabular}{|c|c|c|c|c|}
\hline Sample & $\begin{array}{c}\text { FAEE } \\
\text { content [\%] }\end{array}$ & $\begin{array}{c}\text { Diesel } \\
\text { content }[\%]\end{array}$ & $\begin{array}{c}\text { Cold flow im- } \\
\text { prover content }\end{array}$ & $\begin{array}{c}\text { CFPP } \\
{\left[{ }^{\circ} \mathrm{C}\right]}\end{array}$ \\
\hline B50 & 50 & 50 & $4000 \mathrm{ppm}$ & -25 \\
\hline B70 & 70 & 30 & $4000 \mathrm{ppm}$ & -23 \\
\hline B80 & 80 & 20 & $4000 \mathrm{ppm}$ & -21 \\
\hline
\end{tabular}

Table 4 shows result of the cold flow properties improvement on the way of dosing mineral Diesel fuel and cold flow improving additives. It is noticeable, that the fuel, which contains $70 \%$ of FAEE and the cold flow improvement additives shows a balance between the FAEE content and low temperature behavior of the fuel.

\section{Improvement of compression ignition behaviour of BIOXDIESEL fuel}

Selected properties of the FAEE, FAME and Diesel fuel are presented in Table 1. The properties of ethyl and methyl esters are very close to the properties of mineral fuel. The main differences, except cold flow properties, are related to cetane number and calorific values of the fuels. The properties of mineral Diesel fuel are slightly higher than in esters. The differences can be easily equalized on the way of dosing of the cetane number improving additives and blended with small amount of standard Diesel fuel.

Table 5 shows the results of the cetane number improvement of the BIOXDIESEL fuel. The fuel contained $70 \%$ of the bio-components (FAEE and bioethanol) and $30 \%$ of mineral Diesel. One can notice, that the careful addition of the cetane number improvers enables to meet the requirements given in the standards, describing the properties of Diesel fuel (eg. PN-EN 590).

Table 5. Results of cetane number measurement as a function of cetane number improver content

\begin{tabular}{|c|c|c|c|}
\hline Sample & $\begin{array}{c}\text { FAEE + Bioetha- } \\
\text { nol content [\%] }\end{array}$ & $\begin{array}{c}\text { Cetane number } \\
\text { improver content [ppm] }\end{array}$ & $\begin{array}{c}\text { Cetane } \\
\text { number }\end{array}$ \\
\hline Biox 1 & $70 \%$ & 0 & 48.5 \\
\hline Biox 2 & $70 \%$ & 1500 & 49.4 \\
\hline Biox 3 & $70 \%$ & 3000 & 51.1 \\
\hline
\end{tabular}


5. Determination of energy generated by the engine fed with BIOXDIESEL fuel with various content of cetane number improvers

The procedure of engine testing at non-stationary condition is described in details in $[4,6,7]$. The method is based on the accurate recording of the rotational speed of the crankshaft of the tested engine during cyclical acceleration and deceleration, from idling to maximal engine speed and back to idling. The cyclical changes of engine speed is very similar to the one during smoking test of the vehicles during periodical technical inspection of the vehicle.

The engine rotational speed can be either recorded with a use of encoder (in case of the laboratory engines) or in case of the whole vehicles, the engine speed is recorded with the use of the inductive sensor (similar one to the one used to measure crank shaft or cam shaft position in the engine) and a magnet installed on the crank shaft ending and high speed data acquisition device. The recorded signal is being processed in order to calculate the engine crankshaft rotational speed and angular acceleration.

Assuming, that the polar moment of inertia of the moving parts of the engine is constant, the equation (1) shows relation between torque generated by the engine angular acceleration of the engine crank shaft.

$$
\mathrm{M}=\mathrm{J} \frac{\mathrm{d} \omega}{\mathrm{dt}}=\mathrm{J} \varepsilon
$$

where $\mathrm{M}-$ torque generated by the engine, $\omega-$ angular speed of engine's crank shaft, $\mathbf{J}$ - polar moment of inertia of the rotary parts, $\varepsilon$ - angular acceleration of the engine crank shaft.

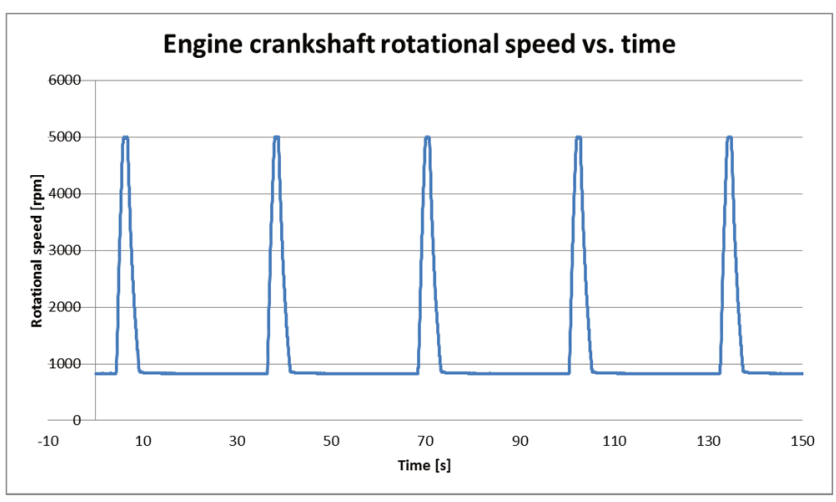

Fig. 2. Example of recorded data (engine crankshaft speed vs. time)

Figure 2 shows cyclical acceleration and deceleration of the engine crankshaft. One can notice, that the acceleration time and deceleration is separated with longer periods with idling speed in order of thermal stabilization of the engine.

The recorded and processed data, drawn on torque vs. engine speed shows loops. It is worth to notice, that the shape of the positive parts of the curves and its area depends on the fuel used for testing. The shape and area of the negative part of the area does not depend on the used fuel.

The value of polar moment of inertia is very difficult to calculate, but this value remains constant for each engine. The testing in non-stationary test can be used for comparison of the engine properties, when the same engine is fed with for example different fuels (see Fig. 3).
The area under the positive part of the curves (Fig. 3) on the torque-engine crankshaft rotational speed plane has the same measures (units) as energy obtained during acceleration of the engine. It is also worth to notice, that the area of the cyclodyne obtained during the test is proportional to the calorific value of the fuel used in the test (see Table 6 and Fig. 3).

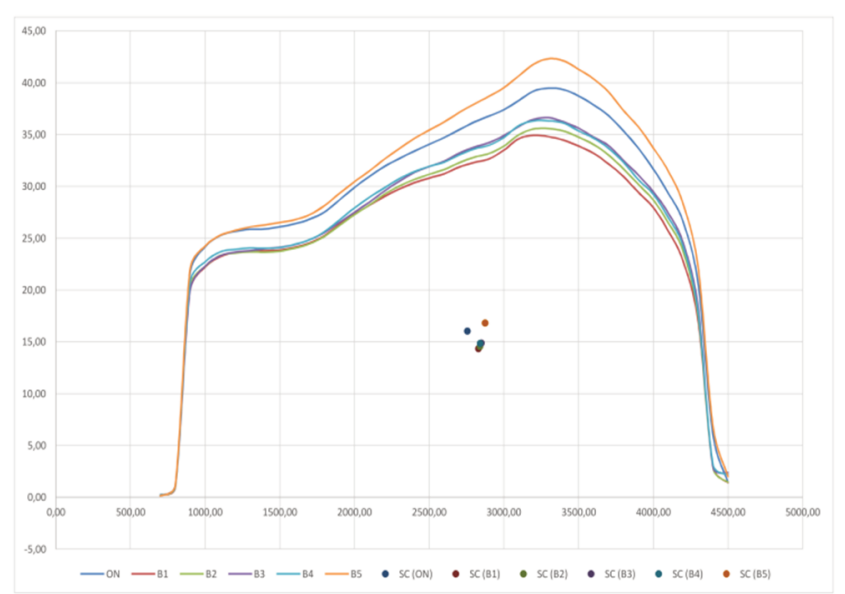

Fig. 3. Example of the positive part of the cyclodynes obtained during the engine test with the fuels with different properties [7] with centres of gravity marked with dots

Table 6. Calorific values of the samples, which testing results are presented in Fig. 3

\begin{tabular}{|c|c|c|c|c|c|c|}
\hline & $\begin{array}{c}\text { Diesel } \\
\text { fuel }\end{array}$ & $\begin{array}{c}\text { Biox } \\
\text { B1 }\end{array}$ & $\begin{array}{c}\text { Biox } \\
\text { B2 }\end{array}$ & $\begin{array}{c}\text { Biox } \\
\text { B3 }\end{array}$ & $\begin{array}{c}\text { Biox } \\
\text { B4 }\end{array}$ & $\begin{array}{c}\text { Biox } \\
\text { B5 }\end{array}$ \\
\hline $\begin{array}{c}\text { Calorific } \\
\text { value } \\
{[\mathrm{MJ} / \mathrm{kg}]}\end{array}$ & 42.8 & 38.1 & 38.3 & 38.4 & 38.2 & 42.4 \\
\hline
\end{tabular}

The area under the curve is proportional to the energy generated by the engine during one cycle of acceleration from idling to maximal crankshaft speed. The acceleration time is measured during one cycle of acceleration; it is the time between idling and maximal crankshaft speed.

Figure 4 presents results of engine test for the BIOXDIESEL fuel with different content of cetane number improving additive. The values of the areas of the cyclodynes have been obtained during a series of acceleration and deceleration of the engine. Each point represents an average of 10 acceleration-deceleration cycles. The fuel used for the test contained $70 \%$ of FAEE and bioethanol with $30 \%$ of mineral Diesel fuel.

The minimal acceleration time and maximal area of the cyclodynes (the positive part of the curves on angular acceleration-engine speed curves) occurs at the same range of cetane number improver content, as the values presented in Table 5. The data presented in Table 5 show the dependence of the cetane number as a function of the cetane number improver content.

It is also worth to notice, that the increase of the cetane number improver content (more than it is recommended either in Table 5 and Fig. 4) is not improving the energy generated by the engine during combustion of the engine. 


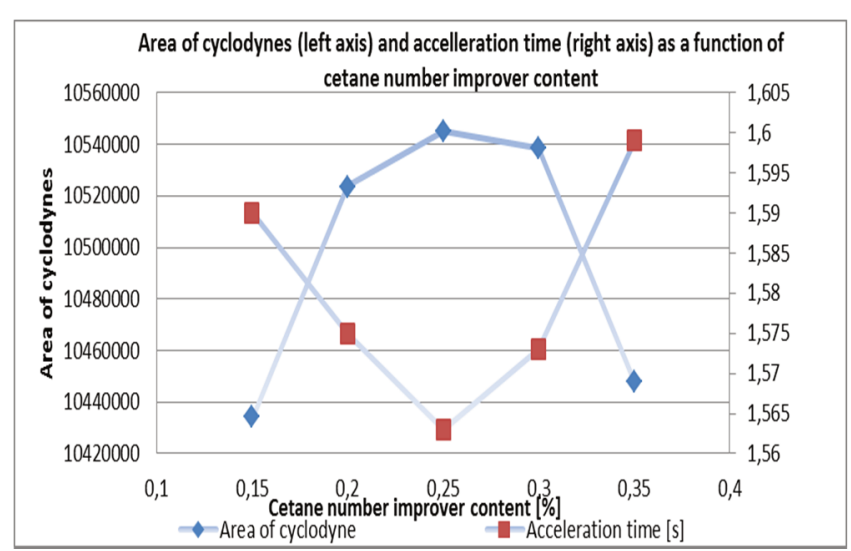

Fig. 4. Area of cyclodyne (left axis) and acceleration time (right axis) as a function of cetane number improver content

\section{Conclusions}

This paper presents research on improvement of the properties of the BIOXDIESEL fuel, which is a mixture of FAEE and/or FAME, bioethanol with addition of mineral Diesel fuel.
The properties of the BIOXDIESEL fuel are very similar to the properties given in the standards for the fuel of the vehicles with compression ignition engines. The cold flow properties of the BIOXDIESEL fuel can be improved by dosing the additives which are improving low temperature behavior of the fuel. This fuel can with the additives can be used even in winter condition in Poland.

Results of measurement presented in this paper also show, that the selection of cetane number improvers can improve compression ignition behaviour of the BIOXDIESEL fuel, which contains large amount of FAEE with addition of mineral Diesel fuel and bioethanol.

It is also worth to notice accordance of the results of determination of cetane number with results of engine tests in non-stationary condition.

Based on the studies presented above and based on previous experience of the authors one can conclude, that the BIOXDIESEL fuel is very advanced and can be used as an alternative fuel for all Diesel engines.

\section{Nomenclature}

FAEE Fatty Acid Ethyl Esters

FAME Fatty Acid Methyl Esters

$\mathrm{CP}$ Cloud Point

\section{CFPP Cold Filter Plugging Point \\ CN Cetane Number}

\section{Bibliography}

[1] BURGER, J.L., LOVESTEAD, T.M., GOUGH, R.V., BRUNO, T.J. Characterization of the effects of cetane number improvers on diesel fuel volatility by use of the advanced distillation curve method. Energy \& Fuels. 2014, 28(4), 2437-2445.

[2] MUSTAFA ERTUNC TAT. Cetane number effect on the energetic and exergetic efficiency of a diesel engine fuelled with biodiesel. Fuel Processing Technology. 2011, 92(7), 1311-1321.

[3] STANIK, W., MAZANEK, A., JAKÓBIEC, J. Study of diesel oil containing 7\% (v/v) of FAME and cetane boost additive for the assessment its utility and purity of injectors. Combustion Engines. 2015, 162(3), 933-943.

Prof. Mieczysław Struś, DSc., DEng. - Faculty of Mechanical and Power Engineering, Wrocław University of Science and Technology

e-mail: mieczyslaw.strus@pwr.edu.pl
[4] STRUŚ, M., POPRAWSKI, W., REWOLTE, M., KARDASZ, P. Feeding the engines of fleet vehicles with Bioxdiesel fuel and heavy alcohols. Journal of KONES Powertrain and Transport. 2016, 23(4), 495-504.

[5] STRUŚ, M., POPRAWSKI, W., REWOLTE, M. Testing the fleet of the vehicles with diesel engines fed by BIOXDIESEL fuel. Combustion Engines. 2017, 170(3), 37-41.

[6] STRUŚ, M. Ocena wpływu biopaliw na wybrane właściwości eksploatacyjne silników. Oficyna Wydawnicza Politechniki Wrocławskiej. Wrocław 2012.

[7] STRUŚ, M., POPRAWSKI, W., REWOLTE, M. Efficiency of feedstock selection for the second generation BIOXDIESEL biofuel for Diesel engines. Combustion Engines. 2015, 3.

Wojciech Poprawski, DEng. - Faculty of Mechanical and Power Engineering, Wrocław University of Science and Technology

e-mail: wojciech.poprawski@pwr.edu.pl 